\title{
Editorial
}

\section{Urban Inequality: The City after the 2007 Crisis}

\author{
Jesús M. González-Pérez
}

Department of Geography, Guillem Colom building, University of the Balearic Islands (Spain), Cra. de Valldemossa km 7.5, 07122 Palma, Spain; jesus.gonzalez@uib.es; Tel.: +34-690-051586

Received: 24 July 2018; Accepted: 30 July 2018; Published: 31 July 2018

\begin{abstract}
After the impact of the 2007 crisis and post-crisis austerity policies, cities are being reconfigured under the auspices of inequality. Social divides are widening, and there is a growing population of excluded and poor people. The urban and welfare state crises of the 1980s are currently being replicated, albeit even more acutely, given that the welfare state in many countries is very weak and there are worrying signs of a crisis of democracy. In the present urban order of globalization, new players have emerged from the financial sector, including investment funds and the so-called vulture funds. Our contribution to this Special Issue is an analysis of urban inequality today based on theoretical and empirical research. The issue includes articles on social movements and resistance in Latin American cities, vulnerability in crisis-hit Spanish cities, and the segregation and quality of basic services in US cities.
\end{abstract}

Keywords: urban inequality; vulnerability; segregation; crisis; urban governance; social movements

"Any city, however small, is in fact divided into two, one the city of the poor, the other of the rich; these are at war with one another" (Plato, The Republic IV, 422B, 380 BC). [1]

One of the main problems of the recent process of urbanization is the increase of the polarization and the social inequalities in the inner city. In the first decade of the 21st century, Michael Pacione (2001) [2] characterized the post-industrial city by the coexistence of four main processes. One of them is the increase of the inequalities, the social and spatial segregation, the privatization of the urban space and increase of the defensible spaces. From an urbanistic point of view, the fragmentation of the urban form is a consequence of many of these processes and an increasingly palpable reality of the city of the 21st century. A growing interest can currently be seen in analysing social polarization, the impact of post-crisis policies and the new social order that have come about from the processes of impoverishment, the risk of declining social mobility, and greater vulnerability and social segregation [3,4]. Over the last 50 years, there have been two key dates linked to greater inequality in cities, and both are related to periods of crisis of capitalism and changes in economic cycles: 1973 and 2007.

The city product of the crisis of 1973 is urbanistically extensive and socially unequal. In the early 21st century, Hammett (2001) [5] stated that most urban inequality between rich and poor came about in the 1980s. Dual cities [6] and divided cities [7] are some of the terms coined from the urban crisis from the 1980s onwards to analyze inequality in late capitalist cities. Nonetheless, Hammett's affirmation should be reviewed in the face of the socio-urban transformations being seen in cities since the 2007 crisis. Initially the crisis and then the neoliberal policies of austerity have not only widened the chasm between social classes and are configuring new urban spaces characterised by segregation and exclusion but have also collectively led to a new stage in investigating urban inequalities. The crisis has dragged a large section of society down into a situation of unprecedented precariousness and social unrest. Alongside this, the current, fragile, and uncertain recovery is spatially imbalanced and 
socially polarizing. In short, we find ourselves in a new period for analysing urban inequality where globalization, in its different analytical perspectives and especially those linked to the world of finance, have brought new agents into the analysis of inequality and opened up new lines of research. In this context, the capitalism-welfare state-democracy trifecta is crumbling. Many of the processes that lead to inequality are common around the world, albeit at different intensities based not only on each country's level of economic development but also, and especially, on the state's protective role and the strength of the welfare state. In this sense and on a large scale, the main differences can be seen between two types of countries: those with high levels of economic development, and a highly developed social safety net and welfare state; and those who have committed to privatized services and the market economy which, in Europe, includes countries in the south and the most recent member states of the European Union.

The analysis of urban inequalities needs new analyzes and interpretations in recent years. The socio-urban consequences of the economic crisis and policies called post-crisis, or austerity, are transforming everyday life in cities around the world. There are processes of impoverishment, increased vulnerability and social segregation, which is producing a new space order. The first public responses to the crisis were dominated by the impulse of neoliberal policies, which are aggravating socio-urban inequalities. The current real estate-financial cycle is producing a new stage of accumulation, albeit without abandoning the processes of dispossession (mortgage foreclosures and repossessions, insecure employment and lower wages, the privatization of social housing, expanding new forms of poverty...). The recession and austerity have had a negative impact on most cities [8]. Authors such as Harvey (2012) and Peck (2012) $[9,10]$ point out that the financial crisis is a particularly urban one. In this way, the consequences of the economic crisis and neoliberal strategies introduced for the recovery have led to fundamental changes in cities: lower investment in public spaces, a halt to urban regeneration, abandoning sustainable mobility policies, the introduction of privatization measures in urban management and planning, etc. Nevertheless, and above all these, we would spotlight the impoverishment of many urban spaces and higher inequality within cities.

Cities are therefore ever more unequal and polarized [11-13]. Even those with the highest economic growth rates have seen increases in the number of people at the risk of exclusion [14]. Societies have fractured into seven or even eight levels, with worryingly large increases among those in precarious circumstances or exclusion. A precariat comprising diverse socio-professional groups in terms of education levels or the type of job they have, but who share a collective experience of precariousness [15]. In this new stage of research into inequality, special focus is placed, on the one hand, on intraurban analysis. Studies into gentrification, vulnerability, or evictions at the neighbourhood level are examples of this trend. On the other, focus is placed on new types of urban agents, mainly those from the world of finance. Investment funds are the main purchasers of land and property in the new property cycle. The so-called vulture funds moved strongly into real estate during the crisis, especially in those countries who most suffered from the bursting of a property bubble.

In this context, the objective of this Special Issue is to study inequalities in the city at different scales and in all territories, from informal settlements and the "urbanization of poverty" in the countries of the South to the fragmentation of the city or urban segregation as global phenomena in the city of the 21st century. In line with this, we have proposed introducing new debates on the city and inequality linked to social movements, urban governance, and access to and quality of drinking water, among other topics.

A total of seven articles have been published in this Special Issue looking at the problems of urban inequality from different perspectives and methodologies. The multi-scale and -sector analysis perspectives contribute to understanding the problems of inequality in cities today. Three articles [16-18] look at cities in countries that were most seriously affected by the Great Recession (Bolivia, Mexico, Argentina, and Brazil in Latin America and Spain as an example from southern Europe). Two articles offer a more theoretical approach [19,20], and a further two are focused on US cities [21,22]. 
The two articles that look as the problem from a more global theoretical scale analyze urban inequality from two different perspectives. In his article "Urbanization and Inequality/Poverty" [19], Brantley Liddle uses different indicators to show the relationship between urbanization and poverty and inequality. The article pays particular attention to urban and rural comparisons, without looking at the socio-urban inequalities within cities. Although increases in GDP per capita unambiguously lower poverty and narrow rural-urban gaps, this paper has confirmed that rapid and excessive urbanization can lead to greater poverty and inequality. In turn, Vojislava Filipcevic ("City Sovereignty: Urban Resistance and RebelCities Reconsidered") [20] includes a major theoretical component in her reflections on the city, inequality, urban commons, and city power from a critical and committed approach. The article argues for an increase in de facto already claimed city sovereignty. If cities are to assume greater capacity to govern and to ensure life, liberty, and the sustainability of their populations, they have to overcome serious constraints in the four domains: surveillance and control of urban space, privatization of public space, the rise of the luxury city, large-scale developments, megaprojects, and homelessness. The article highlights the role played by sanctuary cities that represent "bottom-up sovereignty" and rebel cities, which are similar to rebel governance in the sense that both seek legitimacy that the state has been unable to provide.

Two articles look at cities in Latin America: Brazil, Argentina, Mexico, and Bolivia. Although they use different methodologies and have different objectives, both analyze socio-urban processes linked to the lowest social strata, including the so-called precariat, mainly from the standpoint of social movements and resistance. The paper "Counter Land-Grabbing by the Precariat: Housing Movements and Restorative Justice in Brazil" [16] reflects on Brazilian social housing movements' courageous response to the grave and growing land and housing crisis in Brazil. Professor Irazábal offers an extraordinary paper on social housing movements and the role of Brazil's precariat or lowest-income class in claiming their rights to the city mainly through restorative justice practices. Land occupations by the Movimento dos Trabalhadores Sen Teto and other social housing movements in Rio de Janeiro and São Paulo serve as the basis for the article. In turn, Chryssanthi Petropoulou ("Social Resistances and the Creation of Another Way of Thinking in the Peripheral 'Self-Constructed Popular Neighborhoods': Examples from Mexico, Argentina, and Bolivia" [17]) offers an interesting counterpart to the debates opened up in the previous article. In looking at urban movements, Petropoulou adds an analysis of self-constructed popular neighbourhoods. The article refers to urban social movements, creative social resistances (refers to all those collectivities that offer not only an anti-systemic logic but, also, that express creative action in everyday life), and the collectives that are emerging today in "self-constructed popular neighborhoods." The research is based on the use of qualitative techniques, including interviews and thorough fieldwork in villas in South Greater Buenos Aires, barrios of Ciudad Nezahualcóyotl in the Metropolitan Area of Mexico City, and barrios of El Alto in the Metropolitan Area of La Paz.

The real estate-financial crisis and post-crisis policies introduced since 2007 are having serious socio-urban impacts in countries in southern Europe, especially those who had large property markets. Supported by an interesting mapping, Piñeira, Durán, and Taboada analyze the impacts of the crisis from two points of view. First, to what extent the crisis has impacted the different urban sectors through the analysis of degree of vulnerability. Second, through urban governance, they analyze the proposals to combat vulnerability presented by the ruling parties in their programs for the 2015 municipal elections. Although the case study looks at two medium-sized cities in Spain (Vigo and A Coruna), the first sections analyze urban vulnerability in Spain through different indicators. The article prioritizes research at an intraurban level. In this sense, the authors highlight the need to take action in historical centres, where the loss of centrality and the predominance of an aging population has led to degradation, and in working-class neighbourhoods and the outskirts, where social unrest is increasing.

Two articles look at US cities. Walter, Foote, Cordoba, and Sparks ("Historic Roots of Modern Residential Segregation in a Southwestern Metropolis: San Antonio, Texas in 1910 and 2010") [22] analyze residential segregation in San Antonio (Texas) based on racial patterns. The methodology 
used and the historical analysis are particularly interesting aspects. The article reveals a consistent residential racial pattern as the city core expands over the last century. By 1910, San Antonio was already a remarkably segregated city and the original patterns of residential segregation resemble contemporary San Antonio. Particularly, residential racial segregation in the Hispanic concentrated southwestern portion of the city has increased over time resulting in an exceptionally racially divided metropolis. Finally, in the article "Pipe Dreams: Urban Wastewater Treatment for Biodiversity Protection" [21], Cunningham and Gharipour, inequality is approached from a new variable: the different treatment of wastewater in cities in the United States and its environmental impact, and how this treatment mainly prejudices the poorest urban areas. After a detailed analysis based on case studies, the authors underline three main conclusions: (a) wastewater treatment systems in urban areas of the US are in a state of disrepair leading to significant negative outcomes affecting human and non-human habitats, (b) green wastewater infrastructure strategies that support native hydrology with positive environmental impacts are integral to the protection of the clean water humans and other species rely on for survival, and (c) the use of constructed wetlands in green wastewater infrastructure has great potential to ameliorate biodiversity losses in urban ecosystems while supporting and enhancing densely populated anthropogenic environments with multiple benefits to human health.

In short, in the decade after the start of the last great crisis of capitalism inequality has risen in cities. Three final reflections on the issue: (i) Inequality needs to be mapped; (ii) The territorial spread of the different expressions of inequality and the characterization of the subsequent urban shaping have become increasingly important in the context of the most recent real estate-financial crisis; and (iii) Inequality needs to be confronted by ideas of spatial justice (Soja, 2010) [23], as some governance models are beginning to incorporate. The challenges for the academic and scientific communities are extraordinary. Urban studies must maintain a critical, non-conformist stance in light of the increasing social divisions and urban fragmentation being seen in our cities.

Acknowledgments: This research has been funded by the research project "Crisis and social vulnerability in Spanish island cities. Changes in the social reproduction spaces" CSO2015-68738-P (MINECO/FEDER).

Conflicts of Interest: The author declares no conflicts of interest.

\section{References}

1. Plato. The Republic IV; 380 BC; Alianza Editorial: Madrid, Spain, 2005; ISBN 9788420636733.

2. Pacione, M. Urban Geography. A Global Perspective, 1st ed.; Routledge: London, UK; New York, NY, USA, 2001; ISBN 0-415-34305-4.

3. Koutrolikou, P. Governmentalities of Urban Crises in Inner-City Athens, Greece. Antipode 2015, 48, $172-192$. Available online: https:/ / onlinelibrary.wiley.com/doi/pdf/10.1111/anti.12163 (accessed on 2 July 2018). [CrossRef]

4. Vale, M. Economic crisis and the Southern European regions: Towards alternative territorial development policies. In Identity and Territorial Character. Re-Interpreting Local-Spatial Development; Salom, J., Farinós, J., Eds.; University of Valencia: Valencia, Spain, 2014; pp. 37-48, ISBN 978-84-370-9463-2.

5. Hammet, C. Social Segregation and Social Polarization. In Handbook of Urban Studies; Paddison, R., Ed.; SAGE Publications: London, UK, 2001; pp. 162-176, ISBN 080397695 X.

6. Mollenkopf, J.H.; Castells, M. (Eds.) Dual City: Restructuring New York; Russell Sage: New York, NY, USA, 1991; ISBN 978-0871546081.

7. Fainstein, S.S.; Gordon, I.; Harloe, M. (Eds.) Divided Cities: New York E London in the Contemporary World; Blackwell: Oxford, UK, 1992; ISBN 978-0631181811.

8. URBACT. Cities Facing the Crisis: Impact and Responses; European Union: Saint-Denis La Plaine, France, November 2010; Manuscript of Work. Available online: http://urbact.eu/sites/default/files/import/ general_library/Crise_urbact_16-11_web.pdf (accessed on 26 July 2018). 
9. Harvey, D. The urban roots of financial crises: Reclaiming the city fir anti-capitalist struggle. Soc. Regist. 2012, 48, 1-35. Available online: https:/ / socialistregister.com/index.php/srv/article/view/15644 (accessed on 28 June 2018).

10. Peck, J. Austerity Urbanism. City 2012, 16, 626-655. Available online: https:/ /www.tandfonline.com/doi/ abs /10.1080/13604813.2012.734071 (accessed on 7 July 2018). [CrossRef]

11. Dorling, D.; Ballas, D. Spatial Divisions of Poverty and Wealth. In Understanding Poverty, Wealth and Inequality: Policies and Prospects; Ridge, T., Wright, S., Eds.; Bristol University Press: Bristol, UK, 2008; pp. 103-134, ISBN 978-1861349149.

12. Lemoy, R.; Raux, C.; Jensen, P. Where in Cities Do 'Rich' and 'Poor' People Live? The Urban Economics Model Revisited. Manuscript of Work, HAL. Available online: https://hal.archives-ouvertes.fr/hal-00805116/ (accessed on 26 July 2018).

13. Lennert, M.; van Hamme, G.; Patris, C.; Smetkowski, C.; Ploszaj, A.; Gorzelak, G.; Kozak, M.; Olechnicka, A.; Wojnar, K.; Hryniewicz, J.; et al. FOTI Future Orientations for Cities; ESPON: Brussels, Belgium, 2010. Available online: https:/ / hal.archives-ouvertes.fr/hal-00734406 (accessed on 26 July 2018).

14. EC. Employment and Social Developments in Europe 2012; Publications Office of the European Union: Luxemburg, 2012.

15. Méndez, R. Economías alternativas ¿para una sociedad postcapitalista? Algunas experiencias en Madrid. In XV Coloquio Internacional de Geocrítica; University of Barcelona: Barcelona, Spain, 2018. Available online: http:/ / www.ub.edu/geocrit/XV-Coloquio/RicardoMendez.pdf (accessed on 26 July 2018).

16. Irazábal, C. Counter Land-Grabbing by the Precariat: Housing Movements and Restorative Justice in Brazil. Urban Sci. 2018, 2, 49. [CrossRef]

17. Petropoulou, C.C. Social Resistances and the Creation of Another Way of Thinking in the Peripheral "Self-Constructed Popular Neighborhoods": Examples from Mexico, Argentina, and Bolivia. Urban Sci. 2018, 2, 27. [CrossRef]

18. Piñeira-Mantiñán, M.J.; Durán-Villa, F.R.; Taboada-Failde, J. Urban Vulnerability in Spanish Medium-Sized Cities during the Post-Crisis Period (2009-2016). The Cases of A Coruña and Vigo (Spain). Urban Sci. 2018, 2, 37. [CrossRef]

19. Liddle, B. Urbanization and Inequality/Poverty. Urban Sci. 2017, 1, 35. [CrossRef]

20. Filipcevic Cordes, V. City Sovereignty: Urban Resistance and Rebel Cities Reconsidered. Urban Sci. 2017, 1, 22. [CrossRef]

21. Cunningham, C.; Gharipour, M. Pipe Dreams: Urban Wastewater Treatment for Biodiversity Protection. Urban Sci. 2018, 2, 10. [CrossRef]

22. Walter, R.J.; Foote, N.; Cordoba, H.A.; Sparks, C. Historic Roots of Modern Residential Segregation in a Southwestern Metropolis: San Antonio, Texas in 1910 and 2010. Urban Sci. 2017, 1, 19. [CrossRef]

23. Soja, E. Seeking Spatial Justice; University of Minnesota Press: Minneapolis, MN, USA, 2010; ISBN 9780816666683. 